\title{
How much is a public park worth? An ex ante methodology for impact and cost-benefit analysis on the example of Millenáris Széllkapu in Budapest
}

\author{
Vera Iváncsics ${ }^{1,3}$, Zsolt Szendrei $^{2,3}$, József Obertik $^{3}$, Gábor Balás ${ }^{3}$ \\ ${ }^{1}$ Szent István University, ${ }^{2}$ Budapest University of Technology and Economics, \\ ${ }^{3}$ HÉTFA Research Institute, Hungary
}

\begin{abstract}
Establishing a public park raises a number of methodological issues. The model worked out by HÉTFA Research Institute is suitable for cost-benefit analysis and ex ante viability test of a public park integrated into urban landscape. The paper presents the model by the example of a planned public park at one of the busiest centers of Budapest, the junction of Margit Boulevard and Millennium Park. Such a comprehensive economic evaluation for public parks has not been made in Hungary. First the mechanism of effects was set up, and by using the hedonic price method the project's costs and benefits were presented with national and international statistical indicators and benchmarks. The investment, that has been started in 2016 with in the initial planning and demolition pays for itself by 2019. The results are tested with sensitivity analysis, which has inter alia shown that if we count by the general approach of the project management - costs are expected to increase by $10 \%$ and benefits are to reduce by $10 \%$ - investment returns for the city and their inhabitants for 2030 . Furthermore, without the effect of property appreciation - the investment turns positive by 2061 thanks only to indirect social, economic, environmental benefits. According to our analysis, the park's development, which relaxes a built-in highly populated urban fabric, has become an economically profitable investment as a result of significant beneficial external effects.
\end{abstract}

Keywords: public park, cost-benefit analysis, hedonic pricing, impact analysis, urban green infrastructure

\section{Introduction}

The importance of creating urban green spaces in urbanism goes back to the beginning $20^{\text {th }}$ century, and the idea first published by Patric Geddes in Cities in Evolution form 1915 [55]. From now the necessity and positive social $[98 ; 63 ; 31 ; 81 ; 106$; $12]$, ecological $[102 ; 52 ; 115 ; 86]$ and economic $[104 ; 31 ; 72 ; 88 ; 73 ; 135]$ effects of green spaces are well known. Despite of this fact, at first sight it is more attractive to build in an empty plot in centrally located, urban environment, than establishing a new park for investors and decision-makers. According to our point of view, the main reason for this is the logic of the investor, who counts on the profit of the built-in site and does not have to take into account the costs and benefits of those who are not directly involved in the investment, like inhabitants from neighbourhood or users of the surrounded public places. Encouraging investments that are useful for society, therefore, are regulatory responsibility.

However several international case study exist for assessing effects socio-environmental and economic impacts and a preliminary cost-benefit analysis of investments $[62 ; 117 ; 12]$ also several are sepcialised for parks and green surfaces in urban landscape for example in Tucson (USA) [98], in Joensuu (Finland) [140] in Boston (USA) [134], in Zhuhai (China) [30], in Hongkong (China) [73], in Taiwan [127], in Aalborg (Denmark) [112], in Hungary only few studies deal with the value of green spaces $[135 ; 84]$. May be that is the reason for lack of interest from regulatory bodies in Hungary. Taken into account the former mentioned studies, several different aspects exist, but such a complex research was not found during the literature review. The developed new framework of impact and costbenefit analyses takes into account all aspects of the investment. The methodology can be applied to other domestic and international examples, taking into account specificities, like climate driven benchmarks.

The methodology sets the business as usual (BAU) situation for the basis of the assessment. The set-up mechanism of impacts can generally be used for any public park in any urban landscape, however, severity of the impacts may vary considerably. In the presented example, all effects were evaluated, with one the limitation: not all of them were quantifiable. Some were characterized quantitatively, while others were characterized qualitatively. Quantification was carried out along the hedonic method. A conservative approach was applied: usually the arithmetic average of the benchmark data or the median value of the large deviations were used, but in the case of uncertainty, we used a negative impact with a professional estimate. The effects of abandoned quantification are small, but the result is more positive, so their omission also strengthened our conservative 
estimation. We controlled the dependence of the input data through sensitivity analysis.

The methodology was used in the preliminary cost-benefit analysis of the project of Millenáris Széllkapu, in Budapest, Hungary as an illustration of our results. The applied methodology is new in both domestic and international literature, no such work has been done for the construction of a park so far.

\section{Methodology}

\section{Mechanism of impacts}

Several literatures are dealing with the impact analysis of urban parks. Rodenburg et al. [117] have divided their comprehensive indicator system to four main groups: socio-economic (availability, usability, multifunctionality, training, etc.), environmental (regulation, function preservation), quality (aesthetics, delimiting functions), financial (authorities, funding).

From this grouping it is visible that the impact of the parks is multifaceted, with many stakeholders. Urban green surfaces help reduce air pollution by absorbing environmental pollutants, thereby reducing adverse health effects and improving air quality, and maintaining air purity $[101 ; 107 ; 49]$. Increasing biodiversity and creating a connection with the natural environment [52], contributing to strengthening urban sustainability, creating and sustaining urban ecosystems through the reinforcement of the network system for green spaces, creating opportunities for species richness growth [86]. In addition, it is important to emphasize that the tree to be planted has a value that can be expressed in monetary terms besides the ecosystem services [115].

Due to the dense built-up of downtown areas and the large-scale paved surfaces, the temperature modification effect of urban landscape can be observed both in winter and summer, causing a rise in temperature in relation to outlying and nonurbanized areas [136]. This phenomenon of thermal insulation causes an average temperature difference between urban and rural areas of $2.5^{\circ} \mathrm{C}$ [2]. Urban green surfaces contribute to the reduction of thermal insulation and thus result in savings in summer cooling energy partly due to evaporation, partly due to shielding [102; 101].

The unfavourable health impact of overheating was well-perceived during the 2003 European hot flash when there was an order of magnitude 40,000 more deaths among older people due to extreme weather conditions [54]. However, by a park, an average drop in temperature can be demonstrated to help mitigate all and degenerative mortality [111; 58]. Parks have beneficial health effects beyond thermal insulation. The probability of depression and anxiety disorder, the likelihood of stress or behavioural disturbances decreases near the parks [31; 91; 92; 108]. Among hospital patients, 10\% faster healing and less painful analgesic use can be reached at the park-facing room [9]. The park also contributes to the reduction of average treatment costs [108], reduces the average health costs, the effects depend on the difference between the park and the distance between the parks [61].

A proximity of the parks also contributes to the healthy lifestyle, and measurable health benefits have been demonstrated due to active physical activity [64]. Analyses have highlighted that the use of urban green spaces is therapeutic: the recreational impact of the time spent in a natural environment, as well as the movement, sport and walking [31;12].

Parks in dense urban landscape have a significant sociocultural and recreational impact. According to a survey in Helsinki, easy access of high-quality parks greatly increased the number of visits and park traffic [106]. In Amsterdam, respondents raised the relaxation, the natural environment, the city outgrowth, and the common times spent with children as the main cause of park use [31].

International studies have shown a positive willingness to pay for parks, which draws attention to the strong influence of parks on surrounding urban landscape and its important role in everyday life $[85 ; 9 ; 127]$. Parks also contribute to increasing the attractiveness of the city, which generates economic benefits [31]. The proximity of urban green spaces has a strong impact on the value of nearby real estate, and the urban spaces and parks that have been developed in a qualitative way have a role to play in price management [40]. There is a negative relationship between the price of the property and the distance from the park: the closer we get to the park, the stronger the enhancing effect on the property value [104]. It also has a positive effect when the apartment looks directly at the park [88;73;72,]. In Budapest Takács [135] also demonstrated the influence of parks and urban green spaces on real estate value in domestic conditions.

Based on the above-mentioned literature, we have set up the impacts that can be expected from the establishment of the park and their correlations.

\section{Approbation of the method}

The methodology can be traced back to five steps according to the following:

1. Basis of the assessment: stating position for the comparative assessment of investment

2. Mechanism of impacts: Setting up economic, social and environmental impacts and impact mechanism

3. Evaluation methodology: Definition of impact assessment and quantification methodologies

4. Cost-benefit analysis: Comparison of planned expenditures and expected benefits

5. Sensitivity analysis: dependence control of input data (Figure 4). 


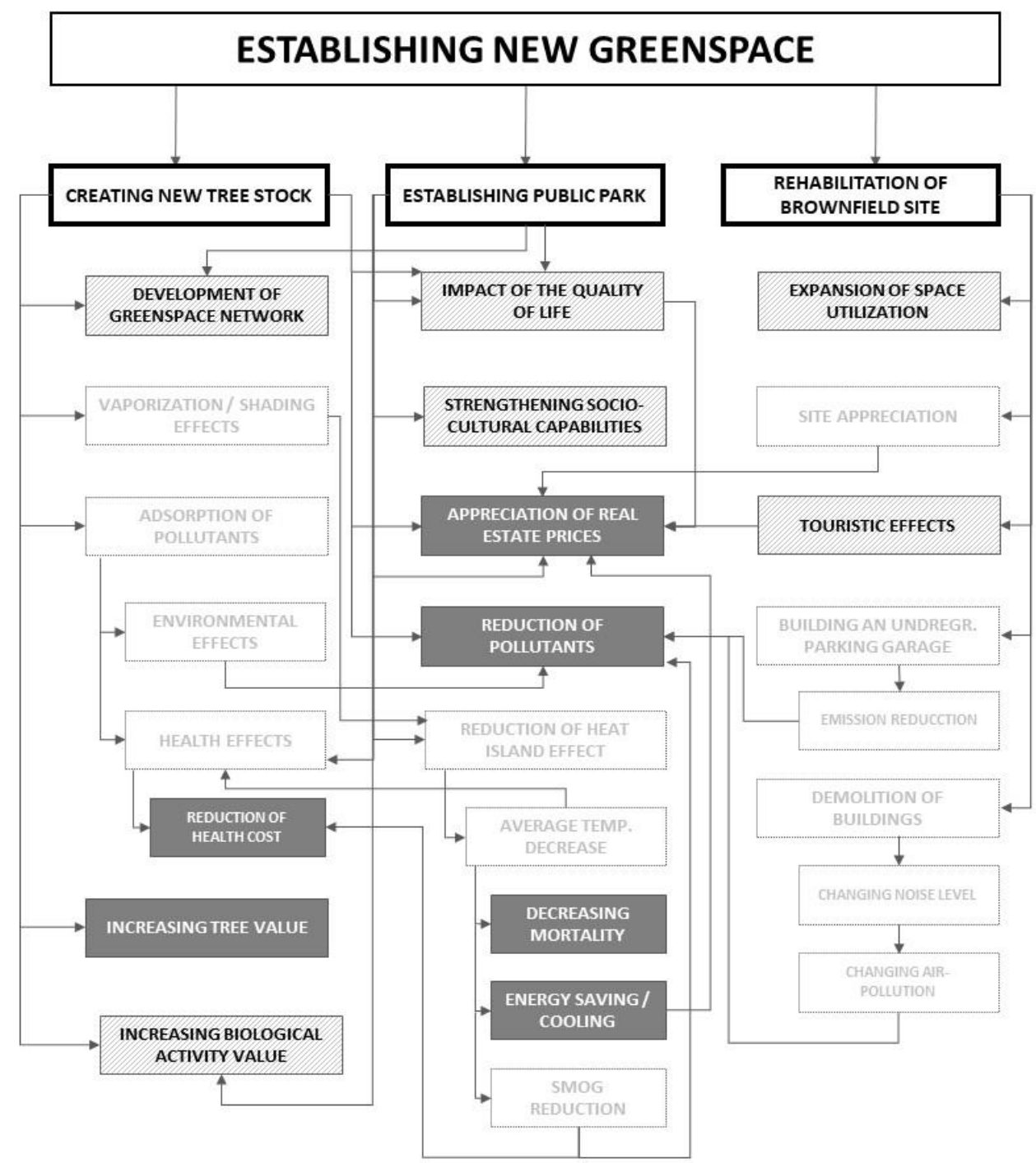

Fig. 1. Impacts and mechanisms considered [authors material]

\section{Development area}

Millenáris Széllkapu is located in the immediate vicinity of Széll Kálmán Square in the center of Budapest. Its area is 2.4 ha, similar to Central Park Zoo, Manhattan, New York or Square LouiseMichel at Montmartre in Paris, France. In the neighbouring plot on the Margit Boulevard, the outdated building of the ministry was previously dismantled in the initial steps of the investment in 2016. The park to be built on empty land contains the following functions [139]:

- Surface: park, two catering units, BUBI bicycle storage, green wall lookout.

Underground: 500 parking spaces, lowering Fény Street, and other equipment. The plans of the park were known to our study - these were input data -, the demolition and site preparation work has begun.

\section{Basis of the assessment}

It is easy to compare the expected consequences of the project with the business as usual, (BAU) case. However, if there are several possibilities for utilizing an area, more accurate decision can be made by comparing them.

The BAU case, against which we evaluated the positive and negative impacts, has the following characteristics:

- the demolition of the ministry building and Kis Rókus Street buildings will not be realized (related expenses, such as maintenance, are not considered in the analysis);

- the development of the plant stock will not be realised;

- the area is underutilized, it is functionally empty;

- the underground garage will not be realised; 


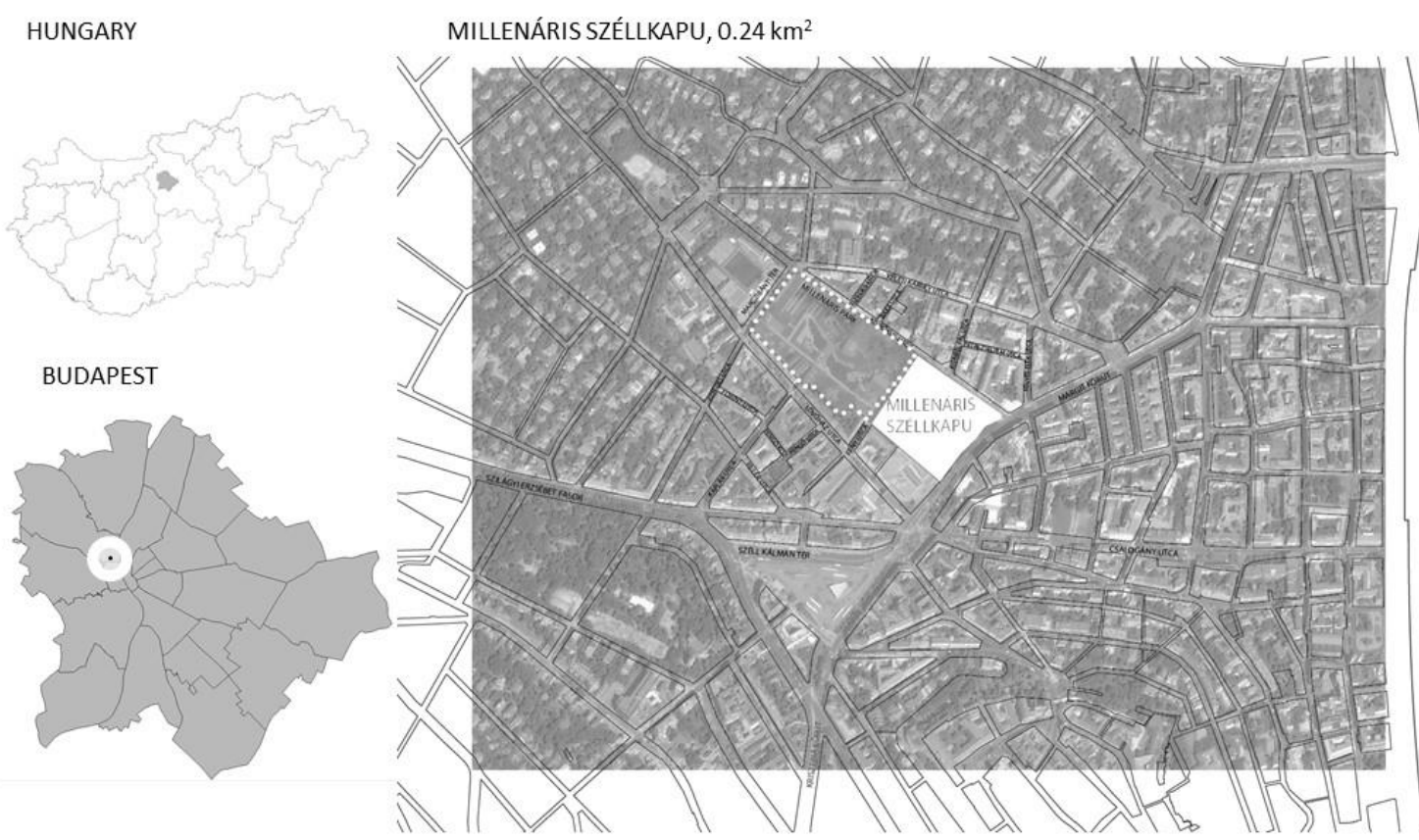

Fig. 2. The development area and its neighbourhood [authors material]
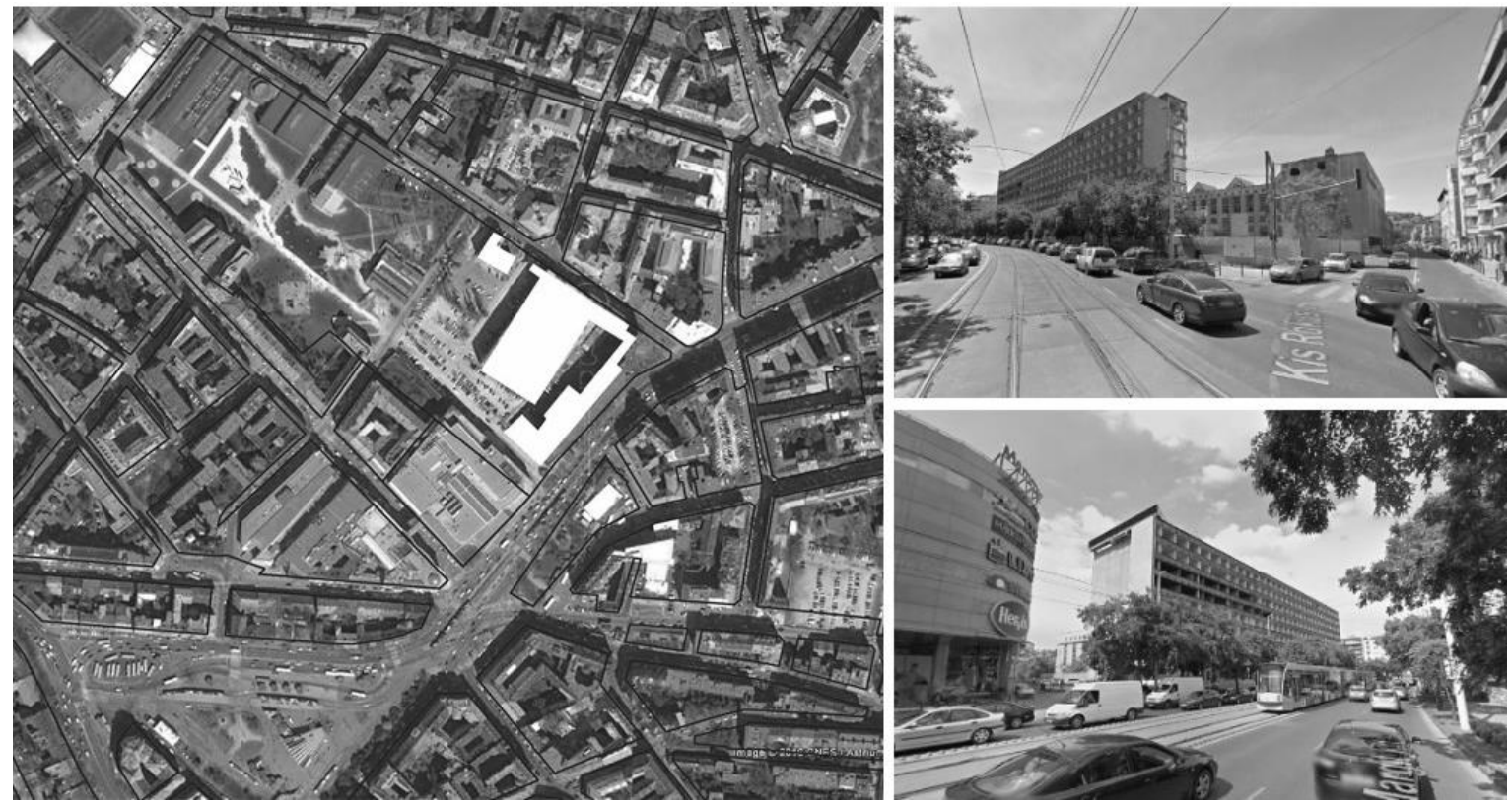

Fig. 3. Business as usual state with the existing ministry building and underutilised sites around it [google.com, just before the demolition]

- no new functions are created, no revenue generating activity is foreseen;

- there is no appreciation for renewal, affecting the area and surrounding city.

\section{Evaluation methodology}

The selection of quantified effects was based on the estimated magnitude of the impact and the uncertainty of its estimation. The effects of which magnitude was negligible or were significant based on the literature were characterized qualitatively. The absence of comparative data could only have been assumed to have an uncertain effect. Since in each case different impacts are being evaluated, it is worth making a survey about the magnitude of the impacts. The survey includes environmental characteristics, people's needs and cultural differences.

There are a number of ways to estimate and quantify the effects of green surfaces. The three most commonly used approaches are travel cost, willingness to pay, and hedonic pricing [98]. In order to quantify the data, we rely primarily on studies using the hedonic method. The method is based on benefits of each object, so it consists of all of their features. For the future park, the expected impact was interpreted as a whole [66]. 
Indicators and benchmarks used to the calculation of ex ante assessment of Millenáris Széllkapu project [authors material]

\begin{tabular}{|c|c|c|}
\hline Indicator & Benchmark & Source \\
\hline \multirow{3}{*}{$\begin{array}{l}\text { Real estate } \\
\text { appreciation }\end{array}$} & $12.22 \%$ (with a direct view) & $88,73,73,112$ \\
\hline & $5.9 \%$ (from 5 minutes' walk zone) & $88,73,10423,7394,84$ \\
\hline & $1.9 \%$ (catchment area) & 94 \\
\hline \multirow{5}{*}{$\begin{array}{l}\text { Heating and } \\
\text { cooling effects and } \\
\text { energy } \\
\text { consumption }\end{array}$} & $3{ }^{\circ} \mathrm{C}$ temperature drop in the summer & $\begin{array}{l}109,122,59,18,107,9, \\
20,131,96\end{array}$ \\
\hline & $-0.65^{\circ} \mathrm{C}$ temperature drop in winter & $\begin{array}{l}\text { own estimates based on } \\
59\end{array}$ \\
\hline & $60 \mathrm{~m}$ expansion of cooling effect & $56,69,22,122,59$ \\
\hline & $\begin{array}{l}3{ }^{\circ} \mathrm{C} \text { effect on cooling energy consumption at } 1{ }^{\circ} \mathrm{C} \text { temperature } \\
\text { drop in the summer }\end{array}$ & $2,120,121,95$ \\
\hline & $\begin{array}{l}3.5 \% \text { growth effect on cooling energy consumption at } 1{ }^{\circ} \mathrm{C} \\
\text { temperature drop in winter }\end{array}$ & 95,46 \\
\hline \multirow[t]{2}{*}{ Health effects } & $1.2 \%$ increase in the mortality at $1^{\circ} \mathrm{C}$ temperature change & 111,58 \\
\hline & $3 \%$ decrease of public health cost & 108 \\
\hline Tree value & $\begin{array}{l}\text { Calculated with precious tree species in a favourable location in } \\
\text { the centre and } 10 \% \text { amortisation in } 5 \text { years. }\end{array}$ & 133, own estimates \\
\hline \multirow{5}{*}{$\begin{array}{l}\text { Reduction of } \\
\text { pollutant }\end{array}$} & $4.5 \mathrm{~kg} / \mathrm{m}^{3} \mathrm{~A}$ tree average carbon absorption & 114 \\
\hline & $\begin{array}{l}5528.22 \mathrm{Ft} \text { social marginal value of one ton of carbon dioxide } \\
\text { emissions }\end{array}$ & 51,143 \\
\hline & $16 \mathrm{~kg} /$ tree annual average dust control & 8,93 \\
\hline & 5.25 million $\mathrm{Ft} / \mathrm{t}$ impact of $\mathrm{PM}_{10}$ emission & 47 \\
\hline & $15 \mathrm{~g}$ savings from emissions reduction of car startup & 80 \\
\hline
\end{tabular}

Different benchmark data were used to quantify impacts from domestic and international literature (methodological description see for example [129; 128]). In present study, data analysis and community benchmarking were conducted based on Stapenhurst [129], which consisted of data collection and literature processing that came from domestic or foreign publications. Functionality was taken into account, where the parks play an equal role in this respect in cities and regions, as the Millenáris Széllkapu park will in Budapest, thus ensuring comparability (this is known as the external validity of comparability). International examples were considered with same size, climatic characteristics, environmental features of the park to be constructed (this is referred to as the internal validity of the comparison).

As benchmarks generally refer to other countries' estimated impacts at other times, it was important and feasible to create equivalent indicators for the year and location of the survey. Two directions were followed: where the data of the study could be formulated as a proportional parameter, those values were used, where not, Hungarian forint, the common domestic currency, in the value of 2016, was calculated using the appropriate exchange rate and GDP deflator. Since the examination was ex ante and a significant part of the benefits and costs are going to be generated in the future, we discounted the $3.25 \%$ interest of the Premium Hungarian State Bond (2016. 11. 25.).

In our example, the effects were divided into two groups: quantifiable and non-quantifiable. Although it was considered important to quantify the impact of the park on the quality of life due to its significant impact, it was nevertheless considered to be an endogenous effect built into a real estate property. Thus, to avoid duplication of the same effects, quantification was not done separately. The quantifiable impacts include the following benchmark-based estimate (Table 1).

ASSESSMENT OF PROPERTIES: an increase in the value of real estate within the "5 minutes walk" or in the wider environment as a one-off revenue (2016 rates).

HEATING AND COOLING ENERGY CONSUMPTION: the decrease in the cooling energy consumption observed due to the summer average temperature decrease and the pricing of the heating energy increase observed in the winter due to the lower temperature decrease (2016 rates).

HEALTH EFFECTS: decreases in public health, voluntary and household health expenditure in the park, and a decrease in mortality due to the reduction of thermal insulation (2016 rates).

TREE VALUE: the initial value of the planted tree stock and its annual growth. 
ENVIRONMENTAL SAVINGS: the role of trees in reducing air pollution, the parking benefits of parking and savings from the $\mathrm{PM}_{10}$ mitigation.

The characterization of non-quantifiable effects is excluded in our study.

Among the calculated effects (assessment of properties, heating and energy consumption, health effects, tree value, environmental savings) several indicators were identified according to literature review to describe the social effects of the planned development. Three types of indicators were included:

- Once occurred income: Calculated once, at the end of the project, e.g. real estate appreciation.

- Current income: Occur every year in the same amount, e.g. reduction of energy consumption, health expenditures, $\mathrm{CO}_{2}$ and dust control savings.

- Continuously growing income: The planted trees are growing every year, so the effects of ecosystem services are also growing. Calculated at $\mathrm{CO}_{2}$ absorption and tree value.

\section{The basis of the projection}

The spatial position of the effects is significantly reduced away from the park. This decreasing effect is true for both real estates and people living there. In present study, surrounding properties and thus the people were divided to different categories: (1) with direct look to the park, (2) who live range of 60 meters, (3) 100 meters or (4) 300-400 meters (5) further catchment area of the park. Apart from a few factors, only the most directly were concerned (1) and $(1+2)$ because of the cautiousness of the estimation results.

\section{Real estate appreciation}

A number of studies have confirmed the positive impact of urban spaces, parks and green spaces on real estate. The most important influencing factor is distance $[104 ; 87 ; 40 ; 73 ; 135 ; 84]$, the view $[72 ; 88 ; 73]$, the nature and conservation of the green surface [89], the green space ratio [105], the increase in park size [112], the street image and public security [87].

We have found empirical results for real estate appreciation between 1.9 and $2.9 \%$, but also between 10 and $16.88 \%$. In the calculations, extreme cases were ignored. As a result, a median value was chosen that was compared to local trends - in our case from Budapest [135].

\section{Heat island effect and energy consumption}

According to the mentioned studies the following effects can be named. In the development of thermal insulation, low vegetation, better heat storage capacity of urban building blocks [70; 32], urban spaces, waste heat emission - building heat and heat of buildings and vehicles $[58 ; 32 ; 77 ; 100 ; 110]$ and the proliferating nature of cities play significant role.
The local microclimate [123] influences the development of energy consumption [2] and human health [11]. Higher temperatures have more health risks $[13 ; 77 ; 132 ; 146 ; 26]$. To reduce this, trees and green infrastructure elements contribute significantly $[144 ; 30]$. The vegetation shadows $[7 ; 60]$ and has better albedo [1] reducing the temperature even from hundreds of meters $[59 ; 45 ; 150]$. The temperature decrease reduces the risk of death $[125 ; 111]$, and the health expenditures [11].

The lower temperature caused by shadowing and evaporating trees in parks $[100 ; 53]$, the winding effect and the increase in surface albedo value plays significant role in the decrease of energy consumption of neighbouring properties decreases $[67 ; 1 ; 2 ; 7]$. The cooling effect of the environment is nearly $3{ }^{\circ} \mathrm{C}$ in the summer [2], which results a noticeable decrease in energy consumption [77]. In contrast, in winter, it has a smaller negative effect, resulting in a cooling effect of less than $1^{\circ} \mathrm{C}$, causing a slight increase in energy consumption [59; 101;28]. The reason for the lower cooling effect observed in winter is the lower the shading ability [36] and evaporative effect of deciduous trees.

\section{Health effects}

The presence of a park encompasses a number of health benefits for the surrounding population and the people who use the park, which has social and monetary economic benefits as well. Many studies have demonstrated the positive correlation between human health and the proximity or use of parks $[90 ; 103 ; 41 ; 57 ; 145$; $42 ; 71 ; 63 ; 50 ; 19 ; 37]$.

Air pollution is absorbed by vegetation in the park [107], the proximity of the parks is favourable for social life [41], sports $[3 ; 35 ; 6 ; 10 ; 1 ; 9 ; 39 ; 113]$. Their effects are measurable in the prevention of psychological illnesses $[149 ; 76 ; 116]$ helps to recover from a stressful state $[79 ; 119 ; 44]$ and prevent its formation [142; 118]. The proximity of parks also reduces average health spending $[108 ; 61]$.

\section{Tree value appreciation}

The theoretical value of a tree goes beyond the direct price, taking into account the ecosystem services and contributions for the social well-being. The applied method, developed by the Hungarian Tree Care Association [133] expresses the economic value and the positive externals also. The most important aspect to calculate the theoretical value is the viability and the condition. In Hungary the evaluation method is based on the Radó-method [115], developed further by the Hungarian Tree Care Association [133].

\section{Reduction of pollutant}

Rehabilitation of a former brownfield site creates a healthier and better urban environment. 


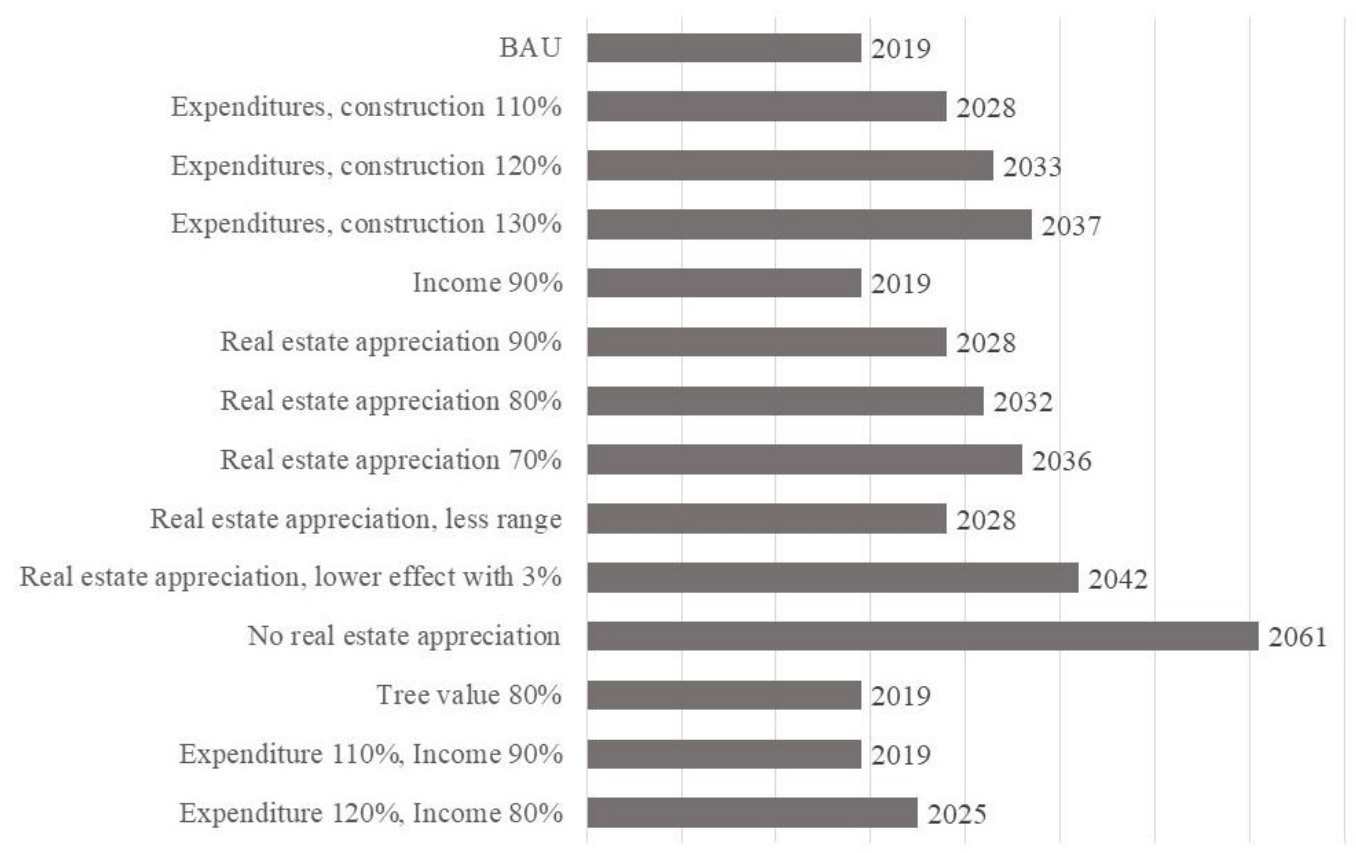

Fig. 4. Results of the sensitivity analysis,

foreseeable return of the project in different scenarios [authors material]

In our case, the flow conditions are influenced in the first place. The $\mathrm{CO}_{2}$ concentration can be reduced by up to $16 \%$, as previously reported by Margit Boulevard [4]. After the demolition of the building the ventilation of the area was solved, the distribution of air pollution concentration was also transformed, resulting in a small improvement in air quality [16].

The UFORE (Urban Forest Effects) model [143], used for USA determination, estimates a $\$ 20.3 / \mathrm{tC}$ unit, which includes the marginal social value of carbon dioxide emissions [51]. For other air pollutants it has an accepted market value for social impacts: $\left[\mathrm{NO}_{2}: 6752 \$ / \mathrm{t}, \mathrm{PM}_{10}: 4508 \$ / \mathrm{t}, \mathrm{SO}_{2}\right.$ : 1653 \$ t t, CO: $959 \$ / \mathrm{t}$ [105]. The trees in the park have a growing carbon capture and absorption capacity $[114 ; 8 ; 93]$ and the dust binding effects [98]. The underground garage also contributes to the reduction of environmental burden, cars are warmed up, which means nearly $50 \%$ less emissions than the cold start $[80 ; 97 ; 65]$. In addition, the surface parking time reduction is reduced, leading to further emission reductions [65].

\section{Further impacts}

The following effects were not used in our estimation, although their qualitative evaluation projected positive effects. However, these effects have been incorporated into the model quantifically:

- Sociocultural relations $[14 ; 147 ; 138 ; 78 ; 5 ; 38$; $24 ; 148 ; 130 ; 74 ; 91 ; 137]$.

- Impact on quality of life $[15 ; 79 ; 119 ; 44 ; 141$; $41 ; 75 ; 27 ; 126 ; 82 ; 83 ; 116 ; 25]$.

- New opportunities for space use.
- Development of the green space network [21].

- Increase in the value of biological activity (based on the values given in Table 2 of Annex 1 of the ÖTM Decree 9/2007 (IV.3).

- Touristic impact $[17 ; 34 ; 124 ; 43 ; 29 ; 79]$.

- Noise and air pollution [68].

\section{Cost-benefit analysis}

Following the impact evaluation, we have prepared our table of yearly costs and profits of the investment, discounted by the year of 2016 . Certain items, of course, have been generated as a one-off effect (e.g. investment cost or property valuation), while others are constantly present during the period under review due to their annual growth. Thus, it was estimated in which year the value of the projected investment will turn into positive, and how many years will it return to society? It is important to see that the return is just the same for the investor with the return, because the investor is the state itself, which is represents the whole society. A market investor would not have a significant part of the benefits of the investment, so without investing in the state, such an investment would probably never be returned to the investor.

\section{Sensitivity analysis}

The impact assessment provides a preliminary estimate and relies on comparative data and benchmarks derived from studies. Therefore, there is a risk of mistake. In such cases, it is common practice to determine the parameters whose erroneous estimation may have the greatest impact on the outcome of the impact assessment. This sensitivity analysis therefore basically serves to 
determine the validity of the estimate and its possible estimation error. It is important to see that sensitivity is two-way. Reality may differ from the estimated value both down and up, but obviously, for a community decision, the higher the risk is the overestimated benefits and underestimated costs. As we have shown above, we have consistently striven for a conservative estimation.

Depending on the types of effects or the risks involved, there are many possibilities for calibrating the sensitivity test. When the possible range of interpretations of some of the known parameters can be used, they can also be used for sensitivity analysis, but we have chosen a simpler approach in our case study: in three steps, we examined whether the difference between $\pm 10 \% \pm 20 \%$ and $\pm 30 \%$ of each parameter would influence the results. The most influencing effects were tested and presented separately (Figure 4).

\section{Results}

\section{Cost-benefit analysis}

The project of Millenáris Széllkapu, the new park in the centre of Budapest, Hungary, turns to positive to 2024. The incomes that occur once are 16.54 billion HUF (real estate appreciation). The current income and continuously growing income are 259.17 million HUF in the first year. The detailed results are described as follows:

- Real estate appreciation in the case study: The calculated real estate appreciation is 16,535 billion HUF. Former real estate appreciations to the site and its neighbourhood were involved $[48 ; 135 ; 66]$

- Heating and cooling effects and energy consumption: For residential buildings the calculated plus in the summer, thanks to shading effects is $153,000 \mathrm{HUF}$, calculated minus in winter 538,000 HUF. (In Hungary the proportion of cooling is low.) For office buildings 4.37 million HUF plus and 3.32 million HUF minus is shown. To sum up, annual profit is 672,000 HUF.

- Health effects: The fiscal profit of the reduced mortality thanks to reduction of heat island effect is 7.83 million HUF annually. The positive effects of the new park produce health savings, 11.52 million HUF for state health care, 808,000 HUF for voluntary health care, 4.85 million HUF for household expenditure. Altogether 25 million HUF annual savings are calculated.

- Tree value: The value of the planned 250 pieces is growing annually, thanks to their ecosystem services growing by age. The value in the first year, after plantation is 840 million HUF. This will grow per year 210 million HUF in the first 10 year.
- Environmental savings: The price of carbon dioxide per tonne is relatively low, the tree absorption (163.08 HUF in the first year) and saving with parking (26.54 HUF in the first year) has low return. However, after 20 years a planted trees absorb the yearly $\mathrm{CO}_{2}$ production of 6 people (calculated with $332 \mathrm{~kg} /$ capita/year by Radó, 2001]. More significant is the saving from dust control. Altogether 23.5 million HUF savings annual is calculated.

The results of the cost-benefit analysis are surprising, because the public return is short, however all benchmarks were calculated in a conservative way (the less ambitious values were chosen to calculate the median of international benchmarks and these were adapted to Hungarian circumstances). For that reason, sensitivity analysis was needed, to see how these results change in different scenarios.

\section{Sensitivity analysis}

The sensitivity analysis tested all parameters of our model in three stages $( \pm 10 \%, \pm 20 \%$ and $\pm 30 \%$ cost reduction or expenditure growth annual in a pessimistic way). The most significant effect is seen with real estate appreciation, so the influenced area was also reduced in our test.

As a result, $10 \%$ change of our parameters did not cause relevant change in our results and the calculated return remained the same. The $20 \%$ change led to remarkable effects at real estate appreciation (return is calculated for 2032) and increase of construction costs (return is calculated for 2033). All other parameters were unaffected. The reduction of range of real estate appreciation increased the return to/for 2028 . The moderate level of real estate appreciation ( $3 \%$, instead of calculated $5.9 \%$ ) resulted a return for 2042 . If the real estate appreciation is not included in the cost-benefit analyses, the return delayed to 2062. With the decrease of all income value by $10 \%$, the prognosed return is 2019. If we calculate the increase of expenditures and decrease of all income in the same time the return is expected to $2019( \pm 10 \%)$ and $2025( \pm 20 \%)$.

\section{Discussion}

The above described model is based on the idea, that not establishing a public park results more risk for the society, because of the underestimated revenues. According to this all advantages of a public park mentioned in the literature were collected and the expectable revenues were calculated in all possible cases. Some advantageous but hardly predictable effects, like benefits of tourism were not considered. Calculation were based on the values mentioned in literature in all case. The benchmarks were adapted to Hungarian circumstances, were calculated in a pessimistic way 
(lower than median/average values, according to experts' estimations).

As it is an ex ante study some information were not available, however the permission plans were already finished. For example, precise parameters of trees were unknown, so we calculated with the planned 250 species, from the best quality of 4-year old nursery product. Older trees were not used in the calculation, however in a park in the centre it would be also reasonable, it would also have a positive impact to our results. In addition to the trees, the value of the shrub stocks or the uniformity of avenue trees can also be expressed in cash, but this was also avoided in our conservative calculations.

In case of BAU costs of maintenance and the positive airing effects of demolishing works were neglected. The site remediation was only included in the calculation of costs, the property value increase after the remediation was also neglected.

Some questions were also faced in connection with the existing park (Millenáris Park) directly next to the investment plot. According to our estimations this does not influence our results, because it has a different function, it is an open space for different events, not a park for recreation. The negative effects of this are printed in the real estate prices. The planned investment will corrugate this effect. However, the real estate appreciation is the most important influencer in our model, as reflected on in the sensitivity analysis. The effect of the existing park is manifested in heat island effects also - it has a remarkable water surface. In the calculations the benchmark value was reduced according to this. Positive health effects away from the plot were not considered, only residents directly neighbourhood of the park were involved.

Such a calculation is applicable to other planned investments, taking account the circumstances of the site and its neighbourhood. These calculations were made in Hungarian Forint (HUF), however, any other currency is suitable for this.

Considering the limitations of our calculations the results go against expectations. The investment of such a park has several positive effects to the society, those were known, but not priced yet. The results are promising, and it would be worth making more calculations to green surface development in built in areas to convince decision makers investors of the competitiveness of establishing public parks in a high-density urban landscape.

\section{Conclusions}

The model and the case study of Millenáris Széllkapu investment is a pioneering work in estimating the effects of public parks. It is well known, that an existing park has several positive effects to the society. Mechanism of this effects was mapped, and an evaluation was carried out. Most of them cannot be estimated because of lack of proper measured data or methodology. In the ex-ante costbenefit analysis the authors focused on the calculatable ones and estimated the long-term incomes in currency (HUF) to get the benefits of the project. The results were compared to expenditures, calculated ex ante by the project management. To validate our results, sensitivity analysis was also performed.

The results are surprising regarding the returns, furthermore several consequences can be made in connection to establishing public parks. In contrast to invertor's attitude, the advantages of a public establishment are realized in wide range. In the case of a public park, this wide range contains all person and economic society uses the catchment area. The finance of a public park is also different, because public money is invested. Externals cannot be understood in the classic way, because all citizen is a stakeholder of the project. In the case of private park, the spread of revenues is limited. According to our estimations, establishing a public park will pay back, if it is situated in an urban landscape with high density, and high property value. In our example the real estate appreciation had the most remarkable influence. That also means that it is worth establishing a park only for real estate appreciation. In a high-density urban landscape, a park establishment do not mean lost revenue for the investor because it increases the value of the plot and appear in the property prices. Several other examples confirm this, like High Lane in Manhattan (NYC) or the success of Kopaszi gát in Budapest, Hungary. Our ex ante analysis confirms this with calculations, according to the model the investment produces a return to 2019 .

It is also surprising that the environmental effects are almost neglectable in estimating the effects of a public park. The extent of air pollution is not influenced by the investment, because the source of the emission stays the same, however the absorption of trees is an important element. Another conclusion that the temperature-balancing effect is remarkable on warmer climate, like in Mediterranean regions. On cooler climate the advantages of shading effect are not so appreciable.

From methodological point of view, we would like to highlight the importance of sensitivity analysis. In the case of ex ante assessments, the identification of predictable effects and the risks of the investment are needed. In parallel with this the calculations based on benchmark values are needed to be prudent, pessimistic and accurate to the local circumstances. These are the key factors of successful assessment. 


\section{References}

1. Akbari, H. Energy saving potentials and air quality benefits of urban heat island mitigation. Lawrence Berkeley National Laboratory, 2005, 20. Retrieved from - http://escholarship.org/uc/item/4qs5f42s

2. Akbari, H., Pomerantz, M., \& Taha, H. Cool surfaces and shade trees to reduce energy use and improve air quality in urban areas. Solar Energy, 2001, 70(3), 295-310. DOI: 10.1016/S0038-092X(00)00089-X

3. Almanza, E., Jerrett, M., Dunton, G., Seto, E., \& Pentz, M. A study of community design, greenness, and physical activity in children using satellite, GPS, and accelerometer data. Health and Place, 2012, 18, 46-54. DOI: 10.1016/j.healthplace.2011.09.003

4. Amorim, J. H., Rodrigues, V., Tavares, R., Valente, J., \& Borrego, C. CFD modelling of the aerodynamic effect of trees on urban air pollution dispersion. Science of the Total Environment, 2013, 461, 541-551. DOI: 10.1016/j.scitotenv.2013.05.031

5. Andorka, R., Kapitány, B., Lengyel, Gy., Spéder, Zs., Szántó, Z., \& Tóth, I. Gy. Bevezetés a szociológiába. Budapest - Osiris. 2006

6. AnonPublication of Surgeon General's report on physical activity and health. MMWR Morb Mortal Wkly Rep, 1996, 45, 591-592. Retrieved from - https://www.jwatch.org/jc199609010000020/1996/09/01/surgeon-generals-reportphysical-activity-and

7. ARUPCities Alive Rethinking green infrastructure. London - Arup, 2014

8. Aston, A. R. Rainfall interception by eight small trees. Journal of Hydrology, 1979, 42, 383-396. doi 10.1016/0022-1694(79)90057-X

9. Atiqul Haq, S. Urban green spaces and an integrative approach to sustainable environment. Journal of Environmental Protection, 2011(2), 601-608. DOI: 10.4236/jep.2011.25069

10. Barton, J., \& Pretty, J. .What is the best dose of nature and green exercise for improving mental health? A multistudy analysis. Environmental Science \& Technology, 2010, 44, 3947-3955. doi - 10.1021/es903183r

11. Bassil, K. L., Cole, D. C., Moineddin, R., Lou, W.,Craig, A. M., Schwartz, B., \& Rea, E. . The relationship between temperature and ambulance response calls for heat-related illness in Toronto, Ontario, 2005. Journal of Epidemiology and Community Health, 2010, 829-831. DOI: 10.1186/1476-069X-13-76

12. Baycan-Levent, T., \& Nijkamp, P. Planning and management of urban green spaces in Europe: Comparative analysis. Journal of Urban Planning and Development 2009, 135(1), 1-12. DOI: 10.1061/(ASCE)07339488(2009)135:1(1)

13. Beckett, K. P., Freer-Smith, P. H., \& Taylor, G. Urban woodlands: their role in reducing the effects of particulate pollution. Environmental Pollution, 1998, 99, 347-360. DOI: 10.1016/S0269-7491(98)00016-5

14. Bell, S., Hamilton, V., Montarzino, A., Rothnie, H., Travlou, P., \& Alves, S. Greenspace and quality of life: a critical literature review. Greenspace Scotland - Stirling, 2008, Retrieved from http://www.openspace.eca.ed.ac.uk/wp-content/uploads/2015/10/Greenspace-and-quality-of-life-a-critical-literaturereview.pdf

15. Bird, W. Natural Thinking. Investigating the links between the Natural Environment. Biodiversity and Mental Health, 2007, 116. Retrieved from - https://www.rspb.org.uk/Images/naturalthinking tcm9-161856.pdf

16. BME A Margit körúti 85-87. szám alatti irodaépület (Hrsz:13204/5) elbontása miatt bekövetkezö levegőminöség és átszellözés változás vizsgálatának eredményei. Budapest. 2013

17. BOP Consulting Green spaces: the benefits for London. London. 2013, Retrieved from $\mathrm{http} / / / \mathrm{www} . c i t y o f l o n d o n . g o v . u k /$ business/economic-research-and-information/researchpublications/Documents/research-2013/Green-Spaces-The-Benefits-for-London.pdf

18. Bowler, D. E., Buyung-Ali, L., Knight, T. M., \& Pullin, A. S. Urban greening to cool towns and cities: A systematic review of the empirical evidence. Landscape and Urban Planning, 2010, 97(3), 147-155. DOI: 10.1016/j.landurbplan.2010.05.006

19. Bratman, G., Daily, G., Levy, B., \& Gross, J. . The benefits of nature experience: Improved affect and cognition. Landscape and Urban Planning, 2015, 138, 41-50. doi - 10.1016/j.landurbplan.2015.02.005

20. Brauer, M., Amann, M., Burnett, R. T., Cohen, A., Dentener, F., Ezzati, M., Henderson, S. B., Michal Krzyzanowski, M., Martin, R. V., van Dingenen, R., van Donkelaar, A., \&Thurston, G. D. Exposure assessment for estimation of the global burden of disease attributable to outdoor air pollution. Environmental science \& technology, 2012, 46(2), 652-660. DOI: 10.1021/es2025752

21. Budapest Green Infrastructure Concept (Budapest Zöldinfrastruktúra Koncepciója). Helyzetelemzés és Értékelés. 2017, 34. Retrieved from - http://budapest.hu/Lapok/Kiemelt-fejleszt $\% \mathrm{C} 3 \% \mathrm{~A} 9 \mathrm{si}-\mathrm{c} \% \mathrm{C} 3 \% \mathrm{~A} 91 \mathrm{lok},-\mathrm{k} \% \mathrm{C} 3 \% \mathrm{~A} 9$ zik\%C3\%B6nyvek.aspx

22. Ca, V.T., Asadea, T. \& Abu, E.M. Reductions in air conditioning energy caused by a nearby park, Energy and Buildings, 29 (1998), pp. 83-92

23. CABE Does money grow on trees? Commission for Architecture and the Built Environment. UK. 2005, Retrieved from - http://webarchive.nationalarchives.gov.uk/20110118095356/http:/www.cabe.org.uk/files/does-money-growon-trees.pdf

24. Canter, D., \& Canter, S. Designing for therapeutic environments. Sussex, UK: John Wiley \& Sons, 1979

25. Carek, P. J., Laibstain, S. E., \& Carek, S. M. Exercise for the treatment of depression and anxiety. The International Journal of Psychiatry in Medicine, 2011(41), 15-28. DOI: 10.2190/PM.41.1.c

26. CDC - Centers for Disease Control Extreme Heat: A Prevention Guide to Promote Your Personal Health and Safety. 2014, 8. Retrieved from - http://emergency.cdc.gov/disasters/extremeheat/ heat_guide.asp.

27. Chang, C., \& Chen, P. Human Response to Window Views and Indoor Plants in the Workplace. HortScience, 2005, 40(50), 1354-1359. DOI: 10.21273/HORTSCI.40.5.1354 
28. Chaparro, L., \& Terradas, J. Ecological services of urban forest in Barcelona. Institut Municipal de Parcs i Jardins Ajuntament de Barcelona, Àrea de Medi Ambient. 2009, Retrieved from - https://www.itreetools. org/resources/reports/Barcelona\%20Ecosystem\%20Analysis.pdf

29. Chaudhry, P. \& Tewari, V. Managing urban parks and gardens in developing countries: A case study from an Indian city. International Journal of Leisure and Tourism Marketing 2010 1. 248-256.

30. Chen Wendy Y. Jim C.Y. Cost-benefit analysis of the leisure value of urban greening in the new Chinese city of Zhuhai, Cities, 2008 25(5) 298-309, DOI: 10.1016/j.cities.2008.06.002

31. Chen, A., Yao, X. A., Sun, R., \& Chen, L. Effect of urban green patterns on surface urban cool islands and its seasonal variations. Urban Forestry \& Urban Greening, 2014, 1-9. doi - 10.1016/j.ufug.2014.07.006

32. Chiesura, A. The role of urban parks for the sustainable city. Landscape and Urban Planning, 2004 (68), 129-138. DOI: $10.1016 / j . l a n d u r b p l a n .2003 .08 .003$

33. Chow, W. T., \& Roth, M. Temporal Dynamics of the urban heat island of Singapure. International Journal of Climatology, 2006, 26, 2243-2260. DOI: 10.1002/joc.1364

34. Cianga, N., \& Popescu, A. C. Green spaces and urban tourism development in Craiova municipality in Romania. European Journal of Geography, 2013, 4(2), 34-45. Retrieved from - http://www.eurogeographyjournal. eu/articles/Greenspaces_Tourism_FINAL.pdf

35. Cohen, D., McKenzie, T., Sehgal, A., Williamson, S., Golinelli, D., \& Lurie, N. Contribution of public parks to physical activity. American Journal of Public Health, 2007, 97(3), 509-514. DOI: 10.2105/AJPH.2005.072447

36. Cohen, P., Potchter, O., \& Matzarakis, A. Daily and seasonal climatic conditions of green urban open spaces in the Mediterranean climate and their impact on human comfort. Building and Environment, 2012, 51, 285-295. DOI: 10.1016/J.BUILDENV.2011.11.020

37. Cohen-Cline, H., Turkheimer, E., \& Duncan, G. Access to green space, physical activity, and mental health: a twin study. Journal of Epidemiology and Community Health, 2015, 69., 523-529. DOI: 10.1136/JECH-2014-204667

38. Comedia, Demos. Park Life: Urban Parks and Social Renewal. Stroud, Gloucestershire, Comedia, 1995, Retrieved from - https://www.demos.co.uk/files/Park_Life_-_web.pdf?1362488185

39. Coombes, E., Jones, A., \& Hillsdon, M. The relationship of physical activity and overweight to objectively measured green space accessibility and use. Social Science and Medicine, 2010, 70, 816-822. DOI: 10.1016/j.socscimed.2009.11.020

40. Crompton, J. L. The impact of parks on property values: a review of the empirical evidence. Journal of Leisure Research, 2001, 33(1), 1-31. DOI: 10.1080/00222216.2001.11949928

41. de Vries, S., Verheij, R. A., Groenewegen, P. P., \& Spreeuwenberg, P. Natural environments - healthy environments? An exploratory analysis of the relationship between green space and health. Environment and Planning A: Economy and Space, 2003, 35(10), 1717-1731. DOI: 10.1068/a35111

42. DEFRA - Department for Environment Food and Rural Affairs Air Pollution: Action in a changing climate. UK, London, 2010, Retrieved from - https:/www.gov.uk/government/uploads/system/uploads/attachment data/file/69340/pb13378-air-pollution.pdf

43. Deng, J., Majumdar, S., Zhang, Y., \& Pierskalla, C. Using contingent valuation to estimate the willingness of tourists to pay for urban forests: A study in Savannah, Georgia. Urban Forestry \& Urban Greening, 2011, 10(4), 275-280. DOI: 10.1016/j.ufug.2011.07.006

44. Depledge, M. H., Stone, R. J., \& Bird, W. J. Can natural and virtual environments be used to promote improved human health and wellbeing? Environmental Science \& Technology, 2011, 45, 4660-4665. DOI: 10.1021/es103907m

45. Doick, K., Peace, A., \& Hutchings, T. The role of one large greenspace in mitigating London's nocturnal urban heat island. Science of the Total Environment, 2014, 493, 662-671. DOI: 10.1016/j.scitotenv.2014.06.048

46. Dole, R. \& Hoerling, M. \& Schubert, S. Reanalysis of Historical Climate Data for Key Atmospheric Features: Implications for Attribution of Causes of Observed Change. A Report by the U.S. CCSP and Subcommittee on Global Change Research. [Randall Dole, Martin Hoerling, and Siegfried Schubert, (eds.) NOAA NCDC, Asheville, NC, 156 pp.. 10.13140/RG.2.1.4747.5046.

47. EEA - European Environment Agency Revealing the costs of air pollution from industrial facilities in Europe. EEA Technical report, No. 15/2011, Retrieved from - http://www.eea.europa.eu/publications/cost-of-air-pollution

48. Eltinga Residential Housing and Energy Efficiency. 2012, Retrieved from http://www.fhbindex.com/FHBIndex/downloads/Housing-and-energy-efficiency/energy-efficiency-in-residential-properties-in-Hungary-2012.pdf

49. Escobedo, F. J., \& Nowak D. J. Spatial heterogeneity and air pollution removal by an urban forest. Landscape and Urban Planning, 2009(90), 102-110. doi - 10.1016/j.landurbplan.2008.10.021

50. Faber-Taylor, A., \& Kuo, F. E. Children with attention deficits concentrate better after walk in the park. Journal of Attention Disorders, 2009(12), 402-409. doi - doi.org/10.1177/1087054708323000

51. Fankhauser, S. The social costs of greenhouse gas emissions: an expected value approach. The Energy Journal, 1994, 15(2), 157-184. DOI: 10.5547/ISSN0195-6574-EJ-Vol15-No2-9

52. Francis, C., \& Marcus, C. C. (Eds.) People Places: Design Guidelines for Urban Open Space. New York John Wiley and Sons, Hoboken, 1997

53. Gao, W. Thermal effects of open space with a green area on urban environment. Part I: a theoretical analysis and its application. Journal of Architecture, Planning and Environmental Engineering, 1993, 448, 15-27. DOI: doi.org/10.3130/aijax.448.0_15

54. García-Herrera, R., Díaz, J., Trigo, R. M., Luterbacher, J., \& Fischer, E. M. A review of the European summer heat wave of 2003. Critical Reviews in Environmental Science and Technology, 2010, 40, 267-306. DOI: doi.org/10.1080/10643380802238137 
55. Geddes, P. Cities in evolution - an introduction to the town planning movement and to the study of civics, Williams in London 1915, 409 p.

56. Givoni, B. Comparing temperature and humidity conditions in an urban garden and in its surrounding areas. Interim Report 1972, no. 2. Building Research Station, Technion: Haifa, Israel.

57. Grahn, P., Lindblad, B., Nilsson, P., \& Ekmann, A. Ute på dagis. Stad och Land, 1997, 145 Hassleholm, Sweden: Norra Skåne Offset. (Outdoors at Daycare. City and Country. In Swedish).

58. Hajat, S., \& Kosatky, T. Heat-related mortality: a review and exploration of heterogenity. Journal Of Epidemiology and Community Health, 2010, 64(9), 753-760. DOI: 10. 1136/jech. 2009.087999

59. Hamada, S., \& Ohta, T. Seasonal variations in the cooling effect of urban green areas on surrounding urban areas. Urban Forestry \& Urban Greening, 2010, 9(1), 15-24. DOI: 10.1016/j.ufug.2009.10.002

60. Hardin, P. J., \& Jensen, R. R. The effect of urban leaf area on summertime urban surface kinetic temperatures: A Terre Haute case study. Urban Forestry \& Urban Greening, 2007, 6, 63-72. DOI: 10.1016/j.ufug.2007.01.005

61. Harnik, P., \& Welle, B. Measuring the Economic Value of a City Park System. The Graham Foundation for Advanced Studies in the Fine Arts, Chicago. In: The Trust for Public Land's Center for City Park Excellence (2009). How Much Value Does the City of Sacramento Receive from Its Park and Recreation System? Sarcramento, [online 03.01.2020.]. http://cloud.tpl.org/pubs/ccpe-econvalueparks-rpt.pdf

62. Hartmann, B., Török, S., Börcsök, E., \& Oláhné Groma, V. Multi-objective method for energy purpose redevelopment of brown field sites. Journal of Cleaner Production, 2014, 82, 202-212. DOI: 10.1016/j.jclepro.2014.07.002

63. Heinze, J. Benefits of Green Space - Recent Research. Environmental Health Research Foundation, Chantilly, 2011 p.28. [online 03.01.2020.]. https://www.emeraldlawncareinc.com/BenefitsofGreenSpace.pdf

64. Herzele, A.V., \& Wiedeman, T. A Monitoring Tool for the Provision for Accessible and Attractive Green Spaces. Landscape and Urban Planning, 2003, 63(2), 109-126. DOI: 10.1016/S0169-2046(02)00192-5

65. Höglund, G. P. Parking, energy consumption and air pollution. Science of the Total Environment, $2004,334-335$, 39-45, DOI: 10.1016/j.scitotenv.2004.04.028

66. Horváth, Á., \& Székely, G. Hedonikus módszer alkalmazása a használt lakások áralakulásának megfigyelésében. Statisztikai Szemle, 2009, 87(6), 594-607

67. Hough, M. City Form and Natural Process. Routledge, London 1989

68. IMSYS Mérnöki Szolgáltató Kft. Környezetvédelmi Tanulmány, Margit körút 85-87. szám alatt található épületek bontása. IMSYS Kft., Budapest 2014

69. Jauregui, E. Influence of a large urban park on temperature and convective precipitation in a tropical city. Journal of Energy and Buildings, 1990, 15(3-4), 457-463. DOI: 10.1016/0378-7788(90)90021-A

70. Jen-Hu C. Report of Ground Temperature. Blue Hill Meteorological Observatory, Milton, Massachusetts, 1958, Vol. I.

71. Jerrett, M., McConnell, R., Chang, C., Wolch, J., Reynolds, K., \& Lurmann, F. Automobile traffic around the home and attained body mass index: A longitudinal cohort study of children aged 10-18 years. Preventive Medicine2009, 50, 50-58. DOI: 10.1016/j.ypmed.2009.09.026

72. Jiao, L., \& Liu, Y.Geographic Field Model based hedonic valuation of urban open space. Landscape and Urban Planning, 2010, 98(1), 47-55. DOI: 10.1016/j.landurbplan.2010.07.009

73. Jim, C. Y., \& Chen, W. Y. Value of scenic views: hedonic assessment of private housing in Hong Kong. Landscape and Urban Planning, 2009, 91(4), 226-234 DOI: 10.1016/j.landurbplan.2009.01.009

74. Jókövi, E. M., \& Luttik, J. Rood en groen - Het combineren van verstedelijking en natuur in de praktijk, Wageningen, The social and economic importance of green and blue areas. 2003, [online 03.01.2020.]. http://edepot.wur.nl/20807

75. Jorgensen, A., Hitchmough, J., \& Dunnett, N. Woodland as a setting for housing - appreciation and fear and the contribution to residential satisfaction and place identity in Warrington New Town, UK. Landscape and Urban Planning, 2007, 79(3-4), 273-287. DOI: 10.1016/j.landurbplan.2006.02.015

76. Kaplan, R. The Role of Nature in the Context of the Workplace. Landscape and Urban Planning, 1993, 26(1-4), 193-201. DOI: 10.1016/0169-2046(93)90016-7

77. Kaplan, R.. The analysis of perception via preference: a strategy for studying how the environment is experienced. Landscape and Urban Planning, 1985, 12(2), 161-176. DOI: 10.1016/0304-3924(85)90058-9

78. Killingsworth, B., Lemay, L., \& Peng, T. Concrete's Role in Reducing Urban Heat Islands, Concrete Sustainability Report. National Ready Mixed Concrete Association, 2014, [online 03.01.2020.]. https://www.nrmca.org/sustainability/CSR09\%20-\%20Concretes\%20Role\%20in\%20Reducing\%20Urban\%20Heat\% 20Islands.pdf

79. Kim, J., \& Kaplan, R. Physical and Psychological Factors in Sense of Community: New Urbanist Kentlands and Nearby Orchard Village. Environment and Behavior, 2004, 36(3), 313-340. DOI: 10.1177/0013916503260236

80. Konijnendijk, C. C., Annerstedt, M., Nielsen, A. B., \& Maruthaveeran, S. Benefits of Urban Parks, A systematic review. Coppenhagen and Alnarp, 2013, [online 03.01.2020.].http://worldurbanparks.org/images/News letters/IfpraBenefitsOfUrbanParks.pdf

81. Környezetvédelmi és Vízügyi Minisztérium (Ministry for Environmental Protection and Water Management) Közlekedjünk Környzetkímélöen. 2013, [online 03.01.2020.]. http:/www.kvvm.hu/cimg/documents/91kozleke djunk_HU_v_gleges.pdf

82. Krenichyn, $\mathbf{K}$. The only place to go and be in the city': women talk about exercise, being outdoors, and the meanings of a large urban park. Health Place, 2006, 12(4). 631-43. DOI: 10.1016/j.healthplace.2005.08.015 
83. Lee, K., Johnson, K., Williams, K., Sargent, L., \& Williams, N. Forget siestas, 'green microbreaks' could boost work productivity. The Conversation. 2015b, [online 03.01.2020.] http://theconversation.com/forget-siestas-greenmicro-breaks-could-boost-work-productivity-42356

84. Lee, K., Williams, K., Sargent, L., Williams, N., \& Johnson, K. 40 second green roof views sustain attention: The role of micro-breaks in attention restoration. Journal of Environmental Psychology, 2015a, 42, 182-189. DOI: 10.1016/j.jenvp.2015.04.003

85. Levegő Munkacsoport A Podmaniczky Park kialakitásának társadalmi hasznai. 2016, [online 03.01.2020.]. https://www.levego.hu/sites/default/files/Podmaniczky_Park_t\%C3\%A1rsadalmi_hasznok_2016marc7.pdf

86. Lo, A. Y., \& Jim, C. Y. Willingness of residents to pay and motives for conservation of urban green spaces in the compact city of Hong Kong. Urban Forestry \& Urban Greening, 2010, 9(2), 113-120. DOI: 10.1016/j.ufug.2010.01.001

87. Loures, L., Santos, R., \& Thomas, P. Urban Parks and Sustainable Development: The case study of Partimao city, Portugal. Conference on Energy, Environment, Ecosystem and Sustainable Development, Agios Nikolaos, Greece, 2007, 127-131.

88. Luther, M., \& Gruehn, D. A városi szabad terek és zöldfelületek területértékre gyakorolt hatása Németorsztágban / The effect of urban open spaces on the value of land in german cities. Tájépitészet (Táj, Település, Kert) Tudományos Szakmai Folyóirat, 2003, 4(1), 17-19.

89. Luttik, J. The value of trees, water and open space as reflected by house prices in the Netherlands. Landscape and Urban Planning, 2000, 48(3-4), 161-167. DOI: 10.1016/S0169-2046(00)00039-6

90. Lutzenhiser, M., \& Neutusil N. R. The effect of open spaces on a home's sale price. Contemporary Economic Policy, 2001, 19(3), 291-298. DOI: 10.1093/cep/19.3.291

91. Maas, J. Vitamin G: Green environments - Healthy environments. NIVEL, Netherlands Institute for Health Services Research, Utrecht, the Netherlands. 2008, [online 03.01.2020.]. https://www.nivel.nl/sites/default/files/ bestanden/Proefschrift-Maas-Vitamine-G.pdf

92. Maas, J., Verheij, R. A., de Vries, S., Spreeuwenberg, P., Schellevis, F. G., \& Groenewegen, P. P. Morbidity is related to a green living environment. Journal of Epidemiology \& Community Health, 2009, 63(12), 967-973. DOI: 10.1136/jech.2008.079038

93. Maas, J., Verheij, R. A., Groenewegen, P. P., de Vries, S., \& Spreeuwenberg, P. Green space, urbanity, and health: how strong is the relation? Journal of Epidemiology \& Community Health, 2006, 60(7), 587-92. DOI: $10.1136 /$ jech.2005.043125

94. Madders, M., \& Lawrence, M. The contribution made by vegetation buffer zones to improved air quality in urban areas. In: Hall, D. O., Myers, N., \& Margaris N. S. (ed.) (1985). Economics in Ecosystem Management.W. Junk, Dordrecht, 1985, 175-181.

95. Maeer, G., Fawcett, G., \& Killick, T. Values and benefits of heritage. A research review. Heritage Lottery Fund. 2012, [online 03.01.2020.]. http://culturehive.co.uk/wp-content/uploads/2013/04/Values-and-Benefits-of-HeritageResearch-Review.pdf

96. Mansur, E. T., Mendelsohn, R., \& Morrison, W. A discrete-continuous choice model of climate change impacts on energy. SSRN Yale SOM Working Paper, 2005, No. ES-43, [online 03.01.2020.]. https://papers.ssrn.com/sol3/papers.cfm?abstract_id=738544

97. Mckeown, D. Green City: Why Nature Matters to Health, Toronto, 2015, [online 03.01.2020.]. http://www.toronto.ca/legdocs/mmis/2015/hl/bgrd/backgroundfile-83420.pdf

98. McMichael, W. F., \& Sigsby Jr., J. E. Automotive Emissions After Hot and Cold Starts in Summer and Winter. Journal of the Air Pollution Control Association, 1966, 16(9), 474-477. DOI: 10.1080/00022470.1966.10468502

99. McPherson, E. G. Accounting for benefits and costs of urban greenspace. Landscape and Urban Planning, 1992, 22(1), 41-51. DOI: 10.1016/0169-2046(92)90006-L

100. McPherson, E. G. Cooling Urban Heat Islands with Sustainable Landscapes. In: Platt, Rutherford H., Rowntree, Rowan A., Muick, Pamela C., eds. The ecological city: preserving and restoring urban biodiversity. Amherst, MA: University of Massachusetts Press 1994, 151-17

101. McPherson, E. G., Nowak, D., Heisler, G., Grimmond, S., Souch, C., Grant, R., \& Rowntree, R. Quantifying urban forest structure, function, and value: the Chicago Urban Forest Climate Project, Urban Ecosystems, 1997, 1(1), 49-61. DOI: 10.1023/A:101435082

102. Meier, A. Strategic landscaping and air-conditioning savings: a literature review. Energy and Buildings, 1990, 15(3-4), 479-486. DOI: 10.1016/0378-7788(90)90024-D

103. Mitchell, R. Is physical activity in natural environments better for mental health than physical activity in other environments? Social Science \& Medicine, 2013, 91, 130-134. doi - 10.1016/j.socscimed.2012.04.012

104. Morancho, A. B. A hedonic valuation of urban green areas. Landscape and Urban Planning, 2003, 66(1), 35-41. DOI: $10.1016 / \mathrm{S} 0169-2046(03) 00093-8$

105. Mourato, S., Atkinson, G., Collins, M., Gibbons, S., MacKerron, G., \& Resende, G. Economic analysis of cultural services. Department of Geography, London School of Economics and Political Science. London, United Kingdom, 2010, [online 03.01.2020.]. http://uknea.unep-wcmc.org/LinkClick.aspx?fileticket=xAcO6D $5 \mathrm{e} 0 \mathrm{UI} \% 3 \mathrm{D} \&$ tabid $=82$

106. Murray, F. J., Marsh, L., \& Bradford, P. A. New York State energy plan, vol. II: issue reports. 1994, Albany, NY: New York State Energy Office.

107. Neuvonen, M., Sievanen, T., Susan, T., \& Terhi, K. Access to Green Areas and the Frequency of Visits: A Case Study in Helsinki. Urban Forestry \& Urban Greening, 2007, 6(4), 235-247. DOI: 10.1016/j.ufug.2007.05.003 
108. Nowak, D. J., \& Heisler, G. M. Air Quality Effects of Urban Trees and Parks. National Recreation and Park Association, 2010, [online 03.01.2020.]. https://www.nrpa.org/globalassets/research/nowak-heisler-researchpaper.pdf

109. Nutsford, D., Pearson, A. L., \& Kingham, S. An ecological study investigating the association between access to urban green space and mental health. Public Health, 2013, 127(11), 1005-1011. DOI: 10.1016/j.puhe.2013.08.016

110. Oke, T. R. Boundary Layer Climates, Second Edition. Taylor\&Francis, London 1987

111. Oke, T. R. The energetic basis of the urban heat island. Quarterly Journal of the Royal Meteorological Society, 1982, 188(455), 1-24. DOI: 10.1002/qj.49710845502

112. Páldy, A. Elsodor a hőhullám - A globális klímaváltozás egészségkárosító hatásai. Lélegzet, 2004, 14(6)

113. Panduro, T. E., \& Veie, K. L. Classification and valuation of urban green spaces - A hedonic house price valuation. Landscape and Urban Planning, 2013, 120, 119-128. DOI: 10.1016/j.landurbplan.2013.08.009

114. Pearce, J., \& Maddison, R. Do enhancements to the urban built environment improve physical activity levels among socially disadvantaged populations? International Journal for Equity in Health, 2011, 10, 28-37. DOI: $10.1186 / 1475-9276-10-28$.

115. Radó D. A növényzet szerepe a környezetvédelemben. Zöld Érdek Alapítvány - Levegő Munkacsoport, Budapest, 2001, [online 03.01.2020.]. http://vmek.oszk.hu/01200/01214/01214.pdf

116. Radó D. Bel- és külterületi fasorok EU-módszer szerinti értékelése. Lélegzet, 1999(7-8)

117. Ribeiro, A. I., Mitchell, R., Carvalho, M. S., \& de Pina, M. de F. Physical activity-friendly neighbourhood among older adults from a medium size urban setting in Southern Europe. Preventive Medicine, 2013, 57(5), 664 670. DOI: 10.1016/j.ypmed.2013.08.033

118. Rodenburg, C. A., Baycan-Levent, T., van Leeuwen, E. S., \& Nijkamp, P. Urban economic indicators for green development in cities. Greener Management International, 2001, 36, 105-119.

119. Roe, J. J., Thompson, C. W., Aspinall, P. A., Brewer, M. J., Duff, E. I., Miller, D., Mitchell, R., \& Clow, A. Green space and stress: evidence from cortisol measures in deprived urban communities. International Journal of Environmental Research and Public Health, 2013, 10(9), 4086-4103. DOI: 10.3390/ijerph10094086

120. Saadatmand, V., Rejeh, N., Heravi-Karimooi, M., Tadrisi, S. D., Zayeri, F., Vaismoradi, M., \& Jasper, M. Effect of nature-based sounds' intervention on agitation, anxiety, and stress in patients under mechanical ventilator support: a randomised controlled trial. International Journal of Nursing Studies, 2013, 50(7), 895-904. DOI: 10.1016/j.ijnurstu.2012.11.018

121. Sailor, D. J. Relating residential and commercial sector electricity loads to climate: Evaluating state level sensitivities and vulnerabilities. Energy, 2001, 26(7), 645-657. DOI: 10.1016/S0360-5442(01)00023-8

122. Sailor, D. J., \& Pavlova, A. A. Air conditioning market saturation and long-term response of residential cooling energy demand to climate change. Energy, 2003, 28(9), 941-951. DOI: 10.1016/S0360-5442(03)00033-1

123. Shashua-Bar, L., \& Hoffman, M. E. Vegetation as a climatic component in the design of an urban street: An empirical model for predicting the cooling effect of urban green areas with trees. Energy and Buildings, 2000, 31(3), 221-235. DOI: 10.1016/S0378-7788(99)00018-3

124. Shashua-Bar, L., Tsiros, I. X., \& Hoffman, M. Passive cooling design options to ameliorate thermal comfort in urban streets of a mediterranean climate (Athens) under hot summer conditions. Building and Environment, 2012, 57, 110-119. DOI: 10.1016/j.buildenv.2012.04.019

125. Sherer, P. M. The benefits of Parks, Why America Needs More City Parks and Open Spaces. The Trust for Public Land, San Francisco, 2013, [online 03.01.2020.]. http://www.eastshorepark.org/benefits_of_parks\%20tpl.pdf

126. Shimoda, Y. Adaptation measures for climate change and the urban heat island in Japan's built environment. Building Research \& Information, 2003, 31(3-4), 222-230. DOI: 10.1080/0961321032000097647

127. Shin, W. The influence of forest view through a window on job satisfaction and stress. Scandinavian Journal of Forest Research, 2007, 22(3), 248-253. DOI: 10.1080/02827580701262733

128. Song, X., Cho, T., Lang, X, \& Piao, Y. Influencing the Willingness to Pay for Urban Park Service Functions. Journal of Environmental Science International, 2013, 22(10), 1279-1285. DOI: 10.5322/JESI.2013.22.10.1279

129. Spendolini, M. J. The benchmarking process. Compensation and Benefits Review, 1992, 24(5), 21-29. DOI: $10.1177 / 088636879202400505$

130. Stapenhurst, T. The Benchmarking Book: A How-to-Guide to Best Practice for Managers and Practitioners. Oxford, United Kingdom, 2009

131. Sullivan, W. C., Kuo, F. E., \& DePooter, S. F. The fruit of urban nature: vital neighbourhood spaces. Environment and Behavior, 2004, 36(5), 678-700. DOI: 10.1177/0193841X04264945

132. Sung, C. Y. Mitigating surface urban heat island by a tree protection policy: A case study of the woodland, Texas, USA. Urban Forestry \& Urban Greening, 2013, 12(4), 474-480. DOI: 10.1016/j.ufug.2013.05.009

133. Sustainable South Bronx Urban Heat Island Mitigation Can Improve New York's Environment: Research on the Impacts of Mitigation Strategies. 2008, [online 03.01.2020.]. https://dash.harvard.edu/handle/1/12361745

134. Szaller V. Útmutató a fák nyilvántartásához és egyedi értékük kiszámításához. Magyar Faápolók Egyesülete, 2013

135. Tajima, K. New Estimates of the Demand for Urban Green Space: Implications for Valuing the Environmental Benefits of Boston's Big Dig Project. Journal of Urban Affairs, 2003, 25. 641 - 655. DOI: 10.1111/j.14679906.2003.00006.x.

136. Takács, D. Városi szabadterek és szabadtér-fejlesztések ingatlanérték-befolyásoló hatásának elemzése Budapest példáján. Ph.D. thesis, Budapest: Szent István University, 2016., 291 p.

137. Talamon, A. Alacsony energiafelhasználású épületek lehetőségei Magyarországon. Ph.D. thesis, Debrecen: University of Debrecen 2014., 146 p. 
138. Thompson, C., Roe, J., Aspinall, P., Mitchell, R., Clow, A., \& Miller, A. More green space is lined to less stress in deprived communities: Evidence from salivary cortisol patterns. Landscape and Urban Planning, 2012, 105(3), 221-229. DOI: 10.1016/j.landurbplan.2011.12.015

139. Troy, A., Grove, J. A., \&O'Neil-Dunne, J. The relationship between tree canopy and crime rates across an urbanrural gradient in the greater Baltimore region. Landscape and Urban Planning, 2012, 106(3), 262-270. DOI: 10.1016/j.landurbplan.2012.03.010

140. TSPC Group, Plans of Millenáris Széllkapu 2015

141. Tyrväinen, L., Väänänen, H. The economic value of urban forest amenities: An application of the contingent valuation method. Landscape and Urban Planning 1998., 43, 105-118.

142. Ulrich, R. S. Health Benefits of Gardens in Hospitals. International Exhibition Floriade, [online 03.01.2020.]. http://plantsolutions.com/documents/HealthSettingsUlrich.pdf, Retrieved November 2016, 10/12/2016

143. Ulrich, R. S. View through a window may influence recovery from surgery. Science 1983, 224, 420-421.

144. USDA Forest Service i-Tree: Urban Forest Inventory and Analysis, An Urban Forestry Project Profile. Washington D. C., 2004, [online 03.01.2020.]. http://www.umass.edu/urbantree/itree\%20profile.pdf

145. Vidrih, B., \& Medved, S. Multiparametric model of urban park cooling island. Urban Forestry \& Urban Greening, 2013, 12(2), 220-229. DOI: 10.1016/j.ufug.2013.01.002

146. Villeneuve, P. J., Jerrett, M., Su, J. G., Burnett, R. T., Chen, H., Wheeler, A. J., \& Goldberg, M. S. A cohort study relating urban green space with mortality in Ontario, Canada. Environmental Research, 2012, 115, 51-58. DOI: $10.1016 /$ j.envres.2012.03.003

147. Weihe, W. H. Life expectancy in tropical climates and urbanization. In: T. R. Oke (ed.). Urban Climatology and its Applications with Special Regard to Tropical Areas, Geneva: World Meteorological Organization. 1986

148. Weldon, S., Bailey, C., \& O'Brien, L. New pathways to health and well-being: summary of research to understand and overcome barriers to accessing woodland. Forestry Commission, Scotland, 2007, [online 03.01.2020.]. https://www.forestresearch.gov.uk/documents/4840/SERG_New_pathways_for_health_and_ well-being in Scotland.pdf

149. Williams, A. Therapeutic landscapes: the dynamic between place and wellness. University Press of America 1999

150. Wilson, E. O. Biophilia - the Human Bond with Other Species. Harvard University Press: Cambridge, Massachusetts 1986

151. Yu, C., \& Hien, W. N. Thermal benefits of city parks. Energy and Buildings, 2006 38(2), 105-120. DOI: 10.1016/j.enbuild.2005.04.003

AUTHORS:

Vera Iváncsics, senior policy analyst at HÉTFA Research Institute 1051 Budapest Hungary, Október 6. utca 19. and PhD student at Department of Landscape Planning and Regional Development, Faculty of Landscape Architecture and Urbanism, Szent István University, Villányi út 35-43, K Building, H-1118 Budapest, Hungary, ivancsicsvera@hetfa.hu, 0036204728754

Zsolt Szendrei, senior policy analyst at HÉTFA Research Institute and PhD student at Csonka Pál Doctoral School, Faculty of Architecture, BME Budapest Department of Urban Planning and Design Faculty of Architecture Budapest University of Technology and Economics (BME), szendreizsolt@hetfa.hu

József Obertik, junior policy analyst at HÉTFA Research Institute, obertik.jozsef1@gmail.com Gábor Balás, Managing Director of HÉTFA Research Institute and Centre for Analysis, balasgabor@hetfa.hu

Kopsavilkums. Publiskā parka izveidošana rada vairākus metodiskus jautājumus. Pētniecības institūta izstrādātais modelis ir piemērots pilsētu ainavā integrēta publiskā parka izmaksu, ieguvumu analīzei un dzīvotspējas pārbaudei. Rakstā atspoguḷots plānotā publiskā parka piemērs vienā no aktīvākajiem Budapeštas centriem - Margitas bulvāra un Tūkstošgades parka krustojumā. Ungārijā nav veikts šāds visaptverošs publisko parku ekonomiskais novērtējums. Vispirms tika izveidots vides ietekmes mehānisms, un, izmantojot izmaksu aprēķinus, tika salīdzināti nacionālie un starptautiskie statistikas rādītāji un etaloni. Ieguldījums, kas tika uzsākts 2016. gadā līdz 2019. gadam, atmaksās. Rezultāti tika pārbaudīti ar pētījuma analīzi, kas parādīja, ka, saglabājot esošo vispārējo projekta vadības pieeju - projekta realizācijas izmaksas palielināsies par $10 \%$, un ieguvumi samazināsies par $10 \%$. Līdz ar to investīciju atdeve pilsētai un tās iedzīvotājiem veidosies tikai 2030. gadā. Pie nosacījuma, ka nepieaugs īpašuma vērtība, tad līdz 2061. gadam ieguldījums kḷūs pozitīvs, pateicoties netieši pakārtotiem sociālajiem, ekonomiskiem un vides ieguvumiem. Saskaṇā ar pētījuma analīzi par parka attīstību, kas slāpē pilsētas blīvās apbūves slodzi, parks kḷūst par ekonomiski izdevīgu ieguldījumu labvēlīgas pilsēttelpas izveidē. 